\title{
Tripodal transmembrane transporters for bicarbonate
}

\author{
Nathalie Busschaert, ${ }^{a}$ Philip A. Gale, ${ }^{a^{*}}$ Cally J.E. Haynes, ${ }^{a}$ Mark E. Light, ${ }^{a}$ Stephen J. Moore, ${ }^{a}$ Christine \\ C. Tong, ${ }^{a}$ Jeffery T. Davis ${ }^{b}$ and William A. Harrell, Jr. ${ }^{b}$
}

\author{
Received (in $X X X, X X X)$ Xth $X X X X X X X X X 200 X$, Accepted $X$ th $X X X X X X X X X 200 X$ \\ ${ }_{5}$ First published on the web Xth $X X X X X X X X X 200 X$ \\ DOI: $10.1039 / \mathbf{b 0 0 0 0 0 0 x}$
}

Easy-to-make tripodal tris-thiourea receptors based upon tris(2aminoethyl)amine are capable of chloride/bicarbonate transport and as such represent a new class of bicarbonate transport agent.

10 The key roles that anions play in a whole range of biological processes has lead to much recent interest in the design of transporters and channels capable of carrying guests ${ }^{1}$ such as chloride $^{2}$ or bicarbonate ${ }^{3}$ across lipid bilayer membranes. Compounds based on tris(2-aminoethyl)amine (tren) have 15 proven to be effective receptors for a variety of anionic species. ${ }^{4}$ Recently tren-based tris-ureas have been employed by Custelcean as agents to selectively crystallise strongly solvated tetrahedral oxo-anions such as sulfate. ${ }^{5}$ In the anion transport arena, D.K. Smith and co-workers have shown that 20 tren-based tris amides are capable of $\mathrm{HCl}$ co-transport through a dichloromethane phase in a U-tube experiment, ${ }^{6}$ whilst B.D. Smith and co-workers have shown that tren-based receptors containing sulfonamide groups or a mixture of sulfonamide and urea moieties are capable of transporting a phospholipid

25 head group through a lipid bilayer i.e. are capable of displaying flippase activity. ${ }^{7}$ J.T. Davis and co-workers have reported that tren-based receptors with appended catechol groups are capable of transmembrane chloride transport. ${ }^{8}$ In this communication we describe the anion transport properties 30 of a series of simple tris-ureas and tris-thioureas based on the tren scaffold 1-4. The results show that the thiourea derivatives are capable of both chloride/nitrate and more significanly of transporting the more hydrophilic bicarbonate anion via a chloride/bicarbonate antiport mechanism. ${ }^{3}$

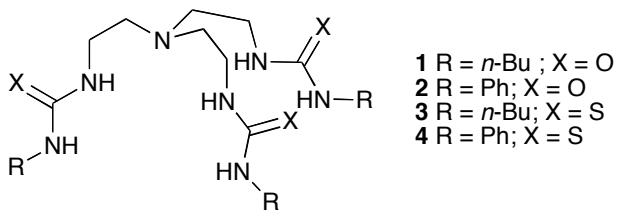

Compounds 1-4 were synthesised by modifications of literature procedures (see ESI). ${ }^{9}$

Proton NMR titration techniques were used to assess the stability of the receptor:anion complexes. Stability constants 40 for the ligand-anion complexes were determined using the EQNMR computer programme. ${ }^{10}$ NMR titrations were conducted in DMSO- $d_{6} / 0.5 \%$ water solutions with tetrabutylammonium anion salts (except for bicarbonate which was added as the tetraethylammonium salt). The results show 45 that in all cases the receptors bind sulfate strongly with $K_{a}>$ $10^{4} \mathrm{M}^{-1}$. Titrations with bicarbonate showed significant downfield shifts of the $\mathrm{NH}$ groups but in all cases, except for compound $3\left(K_{a}=564 \mathrm{M}^{-1}\right)$, the titration curve could not be fitted to a 1:1 binding model despite Job plot analyses so indicating this stoichiometry. Stability constants with chloride of $658,830,447$ and $191 \mathrm{M}^{-1}$ were observed for compounds 1-4 respectively.

Single crystals of the carbonate complex of receptor 4 were grown by slow evaporation of a DMSO/water solution of the ${ }_{55}$ receptor in the presence of excess tetraethylammonium bicarbonate. The X-ray crystal structure revealed that two equivalents of receptor $\mathbf{4}$ bind to a single carbonate anion in the solid state via twelve hydrogen bonds in the range 2.824(6)-3.070(7) $\AA$ with several other longer range $\mathrm{NH}^{\cdots} \mathrm{O}$ 60 interactions (Figure 1a). We have previously observed that anion receptors that form multiple hydrogen bond to oxoanions can perturb the pKa of the guest to the extent that the guest anion is deprotonated by free anion in solution. ${ }^{11}$ This process may also occur here and account for the difficulty in ${ }_{65}$ fitting the bicarbonate NMR titration results to a simple binding model. The structure itself shows the carbonate anion encapsulated between two receptors effectively shielded from the environent external to the complex. The sulfur atoms of the thiourea groups decorate the surface of the capsule-like 70 complex (Figure 1b).

In order to study the chloride transport properties of compounds 1-4 we prepared a series of unilamellar 1palmitoyl-2-oleoylphophatidylcholine (POPC) vesicles loaded with sodium chloride $(489 \mathrm{mM})$ and suspended them in an 75 external $\mathrm{NaNO}_{3}$ (489 mM) solution. A sample of receptor 1-4 or control compound trihexylamine ( $2 \%$ molar carrier to lipid) was added as a DMSO solution and the resultant $\mathrm{Cl}^{-}$efflux monitored using a chloride selective electrode. ${ }^{12}$ After $300 \mathrm{~s}$, the vesicles were lysed by addition of detergent and the final 80 reading of the electrode was used to calibrate $100 \%$ release of chloride. The results are shown in Figure 2 and reveal that compound 1, which contains butylurea groups, does not transport chloride under these conditions. Compound 2, which contains three phenyl urea groups, is more active, 85 whilst compounds $\mathbf{3}$ and $\mathbf{4}$, which contain thiourea groups, and model compound trihexylamine all transport chloride under these conditions, approaching $100 \%$ release over the timescale of the experiment.

There are a number of potential mechanisms that could be 90 responsible for releasing chloride under the conditions of the experiment. We repeated the transport experiments with potassium rather than sodium salts and found no change in the chloride transport rate (evidence against a $\mathrm{Na}^{+} / \mathrm{Cl}^{-}$cotransport mechanism). Further studies in POPC/cholesterol 95 70:30 vesicles showed a reduction in chloride transport rate 
consistent with the compounds $\mathbf{1 - 4}$ functioning as discrete molecular carriers and not as channels. ${ }^{2}$ We also repeated the $\mathrm{Cl}^{-} / \mathrm{NO}_{3}{ }^{-}$experiments in the presence of a $\mathrm{pH}$ gradient and saw little change in the rate of transport of chloride which suggests 5 that $\mathrm{Cl}^{-} / \mathrm{NO}_{3}^{-}$antiport is the predominant mechanism repsonsible for the release of chloride from the vesicles.
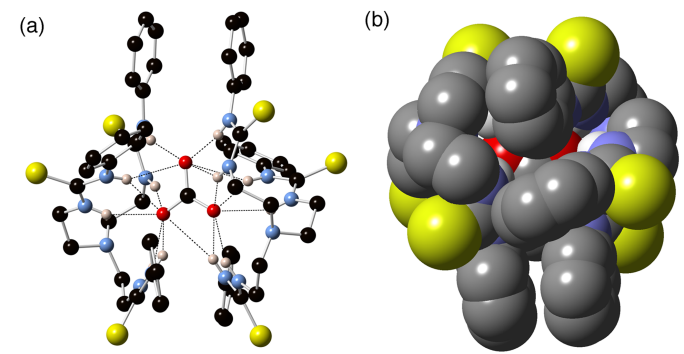

Figure 1 (a) Ball and stick and (b) space-filling views of the carbonate 10 complex of receptor 4 . Counter cations have been omitted for clarity.

We used an HPTS fluorescence assay to study whether the compounds function as $\mathrm{HCl}$ co-transporters with nitrate as the external anion. ${ }^{8}$ Studies were conducted at $4 \%$ molar carrier to lipid concentration. For compounds $\mathbf{2}, \mathbf{3}$ and $\mathbf{4}$ we found that 15 the internal $\mathrm{pH}$ rises initially and then drifts down over the course of the experiment (see Fig. S24 in ESI). This behaviour has been observed previously by Berezin and Davis ${ }^{8}$ and is due to the initial large chloride gradient resulting in a small amount of $\mathrm{HCl}$ co-transport producing a $\mathrm{pH}$ gradient which is

20 then compensated by $\mathrm{HNO}_{3}$ transport into the liposomes on a slower timescale.

We next wished to ascertain whether these compounds could transport bicarbonate through the POPC bilayer. In order to test this, vesicles containing $\mathrm{NaCl}$ were prepared and 25 suspended initially in a solution of $\mathrm{Na}_{2} \mathrm{SO}_{4}$ and a sample of receptor in DMSO solution was added to this suspension $(2 \%$ molar carrier to lipid). In these experiments after a short time a pulse of bicarbonate was added to the external solution. If the compounds can act as $\mathrm{Cl}^{-} / \mathrm{HCO}_{3}{ }^{-}$antiport agents then one 30 would expect that chloride would be released from the vesicles upon addition of bicarbonate. Under the initial conditions of the experiment (i.e. before bicarbonate is added) we would normally expect no release of chloride as sulfate is significantly more hydrophilic than either nitrate or 35 bicarbonate $\left(\left(\Delta \mathrm{G}_{\mathrm{h}}\left(\mathrm{SO}_{4}{ }^{2-}\right)-1080 \mathrm{kJmol}^{-1} ; \Delta \mathrm{G}_{\mathrm{h}}\left(\mathrm{NO}_{3}{ }^{-}\right)-300\right.\right.$ $\left.\mathrm{kJmol}^{-1 ;} \Delta \mathrm{G}_{\mathrm{h}}\left(\mathrm{HCO}_{3}{ }^{-}\right)-335 \mathrm{kJmol}^{-1}\right)^{13}$ and hence sulfate poses a significant challenge to transport through a lipid bilayer. However, note that in the presence of carriers $\mathbf{3}$ and $\mathbf{4}$ chloride was slowly released from the vesicles under the conditions of

40 the experiment (Figure 3). After $120 \mathrm{~s}, \mathrm{NaHCO}_{3}$ was added to the solution, at which point chloride efflux from the vesicles either commenced (compound $\mathbf{2}$ or trihexylamine) or accelerated (compounds $\mathbf{3}$ or $\mathbf{4}$ ). Comparatively these studies show that compound $\mathbf{1}$ is inactive, compound $\mathbf{2}$ and 45 trihexylamine are moderately active bicarbonate transporters whilst compounds 3 and $\mathbf{4}$ both show similar high activity of chloride/bicarbonate transporters (Figure S27 in ESI). ${ }^{3}$

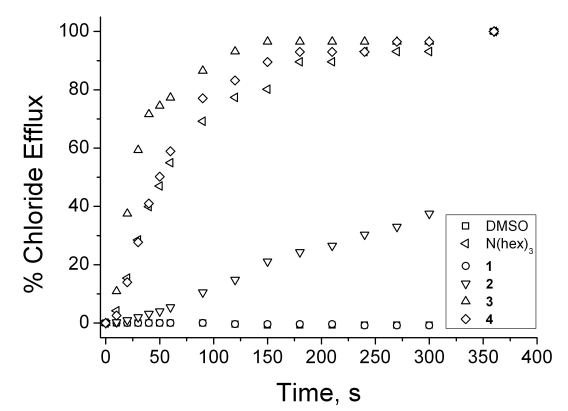

Figure 2 Chloride efflux promoted by 0.02 molar equiv of receptors 1-4 50 and trihexylamine $\left(\mathrm{N}(\text { hex })_{3}\right)$ from unilamellar POPC vesicles loaded with $489 \mathrm{mM} \mathrm{NaCl}$ buffered to $\mathrm{pH} 7.2$ with sodium phosphate salts. The vesicles were dispersed in $489 \mathrm{mM} \mathrm{NaNO}_{3}$ buffered to $\mathrm{pH} 7.2$ with $5 \mathrm{mM}$ sodium phosphate salts. At the end of the experiment, detergent was added to lyse the vesicles and calibrate the ISE to $100 \%$ chloride release. 55 Each point represents the average of three trials.

The experiments depicted in Fig. 3 provided strong, yet indirect, evidence that thioureas $\mathbf{3}$ and $\mathbf{4}$ transport bicarbonate across lipid membranes. We used ${ }^{13} \mathrm{C}$ NMR spectroscopy to gain direct evidence that $\mathbf{3}$ and $\mathbf{4}$ facilitate transmembrane ${ }_{60} \mathrm{HCO}_{3}{ }^{-} / \mathrm{Cl}^{-}$exchange (Fig. 4 and ESI). ${ }^{3 \mathrm{a}}$ In these experiments we monitored bicarbonate efflux from vesicles loaded with $\mathrm{H}^{13} \mathrm{CO}_{3}{ }^{-}$after addition of 1-4. EYPC vesicles filled with $\mathrm{H}^{13} \mathrm{CO}_{3}^{-}$and suspended in $\mathrm{Na}_{2} \mathrm{SO}_{4}$ solution were aged overnight at $4{ }^{\circ} \mathrm{C}$. Two ${ }^{13} \mathrm{C}$ NMR signals separated by $1 \mathrm{ppm}$ ${ }_{65}(\delta \sim 161$ and $\sim 160 \mathrm{ppm})$ were observed, corresponding to signals for intravesicular and extravesicular $\mathrm{H}^{13} \mathrm{CO}_{3}^{-}$(Fig. 4). No leakage of $\mathrm{H}^{13} \mathrm{CO}_{3}^{-}$from these vesicles occurred after addition of $50 \mathrm{mM} \mathrm{NaCl}$. A DMSO solution of the transporters was added to give ligand-to-lipid ratios of 0.04 $70 \mathrm{~mol} \%$ for 1-4. As shown in Fig. 4 thiourea 4 promoted complete $\mathrm{Cl}^{-} / \mathrm{H}^{13} \mathrm{CO}_{3}^{-}$exchange, confirmed by observation of only the NMR signal for extravesicular $\mathrm{H}^{13} \mathrm{CO}_{3}^{-}$. Addition of $\mathrm{Mn}^{2+}$ broadened this $\mathrm{H}^{13} \mathrm{CO}_{3}^{-}$signal into the baseline, confirming that all of the intravesicular $\mathrm{H}^{13} \mathrm{CO}_{3}^{-}$had been 75 exchanged into the extravesicular solution. In sharp contrast, after addition of compound $\mathbf{1}$ the separate signals for intravesicular and extravesicular $\mathrm{H}^{13} \mathrm{CO}_{3}$ remained relatively unchanged. Addition of $\mathrm{Mn}^{2+}$ to this control sample simply erased the extravesicular $\mathrm{H}^{13} \mathrm{CO}_{3}^{-}$signal, whereas the 80 intravesicular $\mathrm{H}^{13} \mathrm{CO}_{3}^{-}$signal remained intact since $\mathrm{Mn}^{2+}$ cannot cross the membrane. This ${ }^{13} \mathrm{C}$ NMR data was consistent with the ISE data in Fig. 3, which showed that thioureas $\mathbf{3}$ and $\mathbf{4}$ are relatively potent anion transporters, whereas urea $\mathbf{2}$ has modest activity and compound $\mathbf{1}$ is ${ }_{85}$ essentially inactive as an anion transporter.

\section{Conclusions}

Compounds $\mathbf{3}$ and $\mathbf{4}$ are easy-to-make and yet effective and potent chloride/bicarbonate transporters that function by an antiport mechanism. ${ }^{3}$ The results clearly show that in these 90 simple tren-based systems, the thioureas are significantly better at transporting bicarbonate anions than are the corresponding ureas (A.P. Davis and B.D. Smith have shown similar effects for chloride transport with functionalised cholapods). ${ }^{13}$ We are currently investigating the oxo-anion 
transport properties of a variety of tren-thiourea derivatives. The results of these studies will be reported in due course.

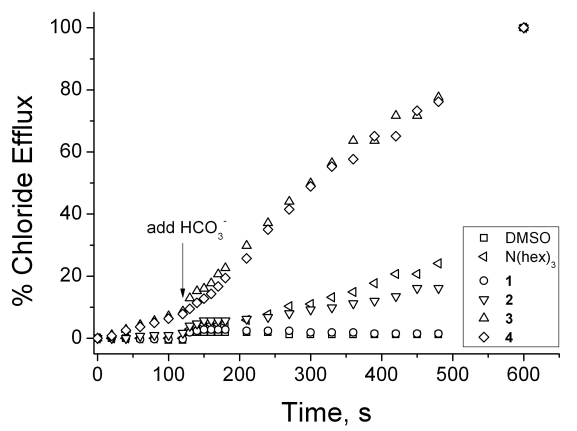

Figure 3 Chloride efflux promoted by 0.02 molar equiv of receptors 1-4 and $\mathrm{N}(\mathrm{hex})_{3}$ from unilamellar POPC vesicles loaded with $489 \mathrm{mM} \mathrm{NaCl}$ buffered to $\mathrm{pH} 7.2$ with $20 \mathrm{mM}$ sodium phosphate salts upon addition of a $\mathrm{NaHCO}_{3}$ pulse to make the extravesicular bicarbonate concentration 40 $\mathrm{mM}$. The vesicles were dispersed in $167 \mathrm{mM} \mathrm{Na}_{2} \mathrm{SO}_{4}$ buffered at $\mathrm{pH} 7.2$ with $20 \mathrm{mM}$ sodium phosphate salts. At the end of the experiment,

10 detergent was added to lyse the vesicles and calibrate the ISE to $100 \%$ chloride release. Each point represents the average of 3 trials.

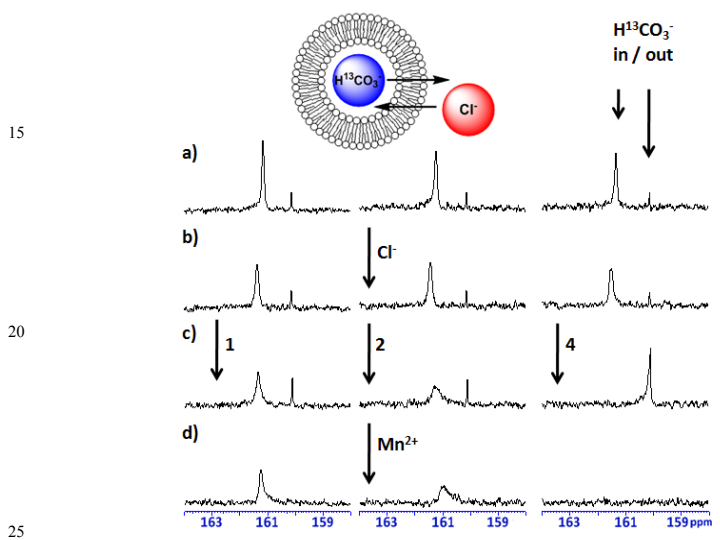

Figure $4{ }^{13} \mathrm{C}$ NMR test for $\mathrm{H}^{13} \mathrm{CO}_{3} / \mathrm{Cl}^{-}$exchange promoted by 0.04 molar equiv. of $\mathbf{1}, \mathbf{2}$, and $\mathbf{4}$. a) before and b) after addition of a $50 \mathrm{mM} \mathrm{NaCl}$ pulse to EYPC vesicles containing $100 \mathrm{mM} \mathrm{NaH}^{13} \mathrm{CO}_{3}$ buffered to $\mathrm{pH} 7.4$ 30 with $20 \mathrm{mM}$ HEPES, dispersed in $75 \mathrm{mM} \mathrm{Na}_{2} \mathrm{SO}_{4}$ buffered to $\mathrm{pH} 7.4$ with 20 mM HEPES; c) after addition of $\mathbf{1}, \mathbf{2}$ or $\mathbf{4} ;$ d) after addition of $0.5 \mathrm{mM}$ $\mathrm{MnCl}_{2}$, a paramagnetic line broadener that only affects extravesicular bicarbonate. See ESI for more data.

\section{Acknowledgements}

${ }_{35}$ We would like to thank the EPSRC and NSF (CHE-0822244) for funding and the EU for supporting NB via the Erasmus programme.

\section{Notes and references}

${ }^{a}$ School of Chemistry, University of Southampton, Southampton, SO17 40 1BJ, UK. E-mail: philip.gale@soton.ac.uk; Fax: +44 (0)23 8059 6805; Tel: +44 (0)238059 3332

${ }^{b}$ Department of Chemistry and Biochemistry, University of Maryland, College Park, MD 20742, USA; E-mail: jdavis@umd.edu

$\uparrow$ Electronic Supplementary Information (ESI) available: Details of 45 synthesis, stability constant determination, crystallography and supplementary membrane transport studies. See DOI: 10.1039/b000000x/ If Please see the ESI for crystal data for this structure.
1 A.P. Davis, D.N. Sheppard and B.D. Smith. Chem. Soc. Rev. 2007, 36, 348-357; J.T. Davis, O. Okunola and R. Quesada, Chem. Soc.

50 Rev. 2010, DOI: 10.1039/b926164h; P.A. Gale, Chem. Soc. Rev., 2010, DOI:10.1039/c001871f; P.A. Gale, Chem. Commun. 2011, DOI $10.1039 / \mathrm{c} 0 \mathrm{cc} 00656 \mathrm{~d}$.

2 A.V. Koulov, T.N. Lambert, R. Shukla, M. Jain, J.M. Boon, B.D. Smith, H.Y. Li, D.N. Sheppard, J.B. Joos, J.P. Clare and A.P. Davis, Angew. Chem. Int., Ed. 2003, 42, 4931-4933; P. A. Gale, M. E. Light, B. McNally, K. Navakhun, K. E. Sliwinski and B. D. Smith, Chem. Commun., 2005, 3773-3775; J. L. Sessler, L. R. Eller, W. S. Cho, S. Nicolaou, A. Aguilar, J. T. Lee, V. M. Lynch and D. J. Magda, Angew. Chem., Int. Ed., 2005, 44, 5989-5992; P. A. Gale, J. Garric, M. E. Light, B. A. McNally and B. D. Smith, Chem. Commun., 2007, 1736-1738; R. I. Sáez Díaz, J. Regourd, P. V. Santacroce, J. T. Davis, D. L. Jakeman and A. Thompson, Chem. Commun., 2007, 2701-2703; P.V. Santacroce, J.T. Davis, M.E. Light, P.A. Gale, J. C. Iglesias-Sánchez, P. Prados and R. Quesada, J. Am. Chem. Soc., 2007, 129, 1886-1887; C.C. Tong, R. Quesada, J.L. Sessler and P.A. Gale, Chem. Commun. 2008, 6321-6323; A. Perez-Velasco, V. Gorteau and S. Matile, Angew. Chem. Int. Ed., 2008, 47, 921-923;; M.G. Fisher, P.A. Gale, J.R. Hiscock, M.B. Hursthouse, M.E. Light, F.P. Schmidtchen and C.C. Tong, Chem. Commun. 2009, 3017-3019;

70 A. Hennig, L. Fischer, G. Guichard and S. Matile, J. Am. Chem. Soc., 2009, 131, 16889-16895; C.R. Yamnitz, S. Negin, I.A. Carasel, R.K. Winter and G.W. Gokel, Chem. Commun. 2010, 46, 2838-2840.

3 J.T. Davis, P.A. Gale, O.A. Okunola, P. Prados, J.C. IglesiasSánchez, T. Torroba and R. Quesada, Nature Chem. 2009, 1, 138144; P.A. Gale, C.C. Tong, C.J.E. Haynes, O. Adeosun., D.E. Gross, E. Karnas, E. Sedenberg, R. Quesada, and J.L. Sessler, J. Am. Chem. Soc. 2010, 132, 3240-3241.

4 For the first example see: S. Valiyaveettil, J. F. L. Engbersen, W. Verboom and D. N. Reinhoudt, Angew. Chem., Int. Ed. Engl., 1993,

80 32, 900-901. For later examples see: C. Raposo, M. Almaraz, M. Martin, V. Weinreich, M. L. Mussons, V. Alcazar, M. C. Caballero and J. R. Moran, Chem. Lett., 1995, 759-760; C. E. Stanley, N. Clarke, K. M. Anderson, J. A. Elder, J. T. Lenthall and J. W. Steed, Chem. Commun., 2006, 3199-3201.

855 R. Custelcean, B.A. Moyer and B.P. Hay, Chem. Commun. 2005, 5971-5973; R. Custelcean, P. Remy, P.V. Bonnesen, D.-e. Jiang and B.A. Moyer, Angew. Chem. Int. Ed. 2008, 47, 1866-1870; R. Custelcean and P. Remy, Cryst. Growth Des. 2009, 9, 1985-1989; R. Custelcean, A. Bock and B.A. Moyer, J. Am. Chem. Soc. 2010, DOI:10.1021/ja101354r. See also : F. Y. Zhuge, B. A. Wu, J. J. Liang, J. Yang, Y. Y. Liu, C.D. Jia, C. Janiak, N. Tang and X. J. Yang, Inorg. Chem., 2009, 48, 10249-10256.

6 K.J. Winstanley, S.J. Allen and D.K. Smith, Chem. Commun. 2009, 4299-4301.

957 J.M. Boon and B.D. Smith, J. Am. Chem. Soc. 1999, 121, 1192411925; Y. Sasaki, R. Shukla and B.D. Smith, Org. Biomol. Chem. 2004, 2, 214-219.

8 S. K. Berezin and J. T. Davis, J. Am. Chem. Soc., 2009, 131, 24582459

1009 R. J. Warr, K. J. Bell, A. Gadzhieva, A. J. Blake, M. Schroeder, A. N. Westra, J. Chartres, R. Ellis, C. Tong, T. G. Simmance and P. A. Tasker, Chem. Eur. J., 2009, 15, 4836-4850; F. Werner and H-J. Schneider, Helv. Chim. Act., 2000, 83, 465-478; M. de Loos, G. J. Alette, J. van Esch, H. Kooijman, A. L. Spek, R. Hage, R. M. Kellogg and B. L. Feringa, Eur. J. Chem., 2000, 22, 3675-3678; R. J. Warr, K. J. Bell, A. Gadzhieva, A. J. Blake, M. Schroeder, A. N. Westra, J. Chartres, R. Ellis, C. Tong, T. G. Simmance and P. A. Tasker, Angew. Chem. Int. Ed., 2008, 47, 1745-1748.

10 M.J. Hynes, J. Chem. Soc. Dalton Trans. 1993, 311-312.

11011 P.A. Gale, J.R. Hiscock, S.J. Moore, C. Caltagirone, M.B. Hursthouse and M.E. Light, Chem. Asian J., 2010, 5, 555-561; P.A. Gale, J.R. Hiscock, C.Z. Jie, M.B. Hursthouse, and M.E. Light, Chem. Sci., DOI:10.1039/C0SC00202J.

12 B.D. Smith and T. N. Lambert, Chem. Commun. 2003, 2261-2268.

11513 B. A. McNally, A. V. Koulov, T. N. Lambert, B. D. Smith, J. B. Joos, A. L. Sisson, J. P. Clare, V. Sgarlata, L. W. Judd, G. Magro and A. P. Davis, Chem. Eur. J., 2008, 14, 9599-9606 


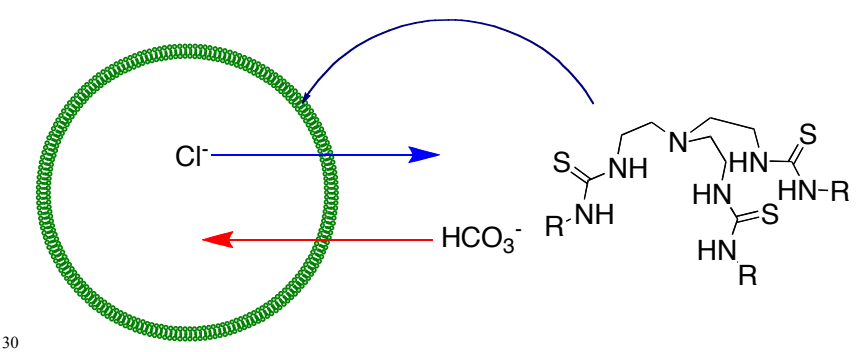

